\title{
Comparison of different media to produce Cymbidium orchids by pseudobulbs
}

\author{
Shahram Sedaghathoor ${ }^{1}$, Gholamreza Golzari Dehno ${ }^{2}$, Rohangiz Naderi ${ }^{3}$, Sepideh \\ Kalatehjari $^{2}$, Behzad Kaviani ${ }^{1}$ \\ ${ }^{1}$ Rasht Branch, Islamic Azad University, Rasht, Iran. E-mail: sedaghathoor@yahoo.com, b.kaviani@yahoo.com \\ ${ }^{2}$ Science and Research Branch, Islamic Azad University, Tehran, Iran. E-mail: gholamreza.golzari@gmail.com, \\ kalatehjari@srbiau.ac.ir \\ ${ }^{3}$ University of Tehran, Karaj, Iran. E-mail: rnaderi@ut.ac.ir
}

Recebido: 27/05/2017; Aceito: 04/09/2017.

\begin{abstract}
Nowadays, Orchids are one of the most commercial products in flower markets. One of the propagation methods for Cymbidium is using old pseudobulbs that are thrown out after flowering period. This research carried out using standard Cymbidium back-bulbs based on randomized complete block design with 5 treatments in 3 replications. The trial traits were leaf length, root length, leaf number and root number that were studied for 180 days. The results show that minimum length of root was significant under different growth beds. The minimum percent of rooting was observed in pure sand treatment. The maximum length was observed in pure perlite. The shortest of leaves were gained in perlite + sand treatment and the maximum leaf length was observed in pure perlite treatment. The maximum average of root percent was seen in pure perlite treatment.
\end{abstract}

Key-words: Cymbidium orchid, back-bulb, perlite, propagation

\section{Comparação de diferentes substratos para a produção de orquídeas Cymbidium a partir de pseudobulbos}

\section{RESUMO}

Atualmente, as orquídeas são um dos produtos comerciais mais importantes do mercado de flores. Um dos métodos de propagação para as orquídeas Cymbidium é com o uso de pseudobulbos velhos que são descartados após o período de floração. Esta pesquisa foi realizada usando pseudobulbos padrão de Cymbidium, dispostos em um delineamento de blocos ao acaso com 5 tratamentos e 3 repetições. Aos 180 dias foram mensuradas as seguintes variáveis: comprimento da folha, comprimento da raiz, número de folha e número das raízes. Os resultados mostram que o comprimento mínimo das raízes foi significativamente afetado pelos diferentes substratos de crescimento. A percentagem mínima de enraizamento foi observada com a utilização de areia pura. $\mathrm{O}$ comprimento máximo foi observado com a utilização de perlita pura. As folhas mais curtas foram obtidas no tratamento com perlita + areia e o comprimento máximo da folha foi observado no tratamento com perlita pura. A máxima de porcentagem de raízes foi observada no tratamento com perlita pura.

Palavras-chave: Orquídea Cymbidium, pseudobulbo, perlita, propagação. 


\section{Introduction}

Iran has the seventh rank in terms of cultivation area of flowers and plants in the world and it is ranked the $107^{\text {th }}$ in terms of exports. Delving into the statistics showed that most products in Iran do not have good quality and cost is not competitive with other exports. Fixing bug in flower production can contribute agricultural macroeconomic programs. Orchid production, especially those with cold and temperate origin, which have geographical and temporal constraints for offering in the global market, can be cultivated in northern Iran (Kiaee, 2011).

Orchid production is recommended in the northern part of Iran due to lower costs of fossil fuels, lack of seasonal frost, easy satisfaction of moisture and light requirements with the least cost, and local potential. The climate of northern Iran allows the production of orchids with reasonable prices at the peak demand of the northern hemisphere market, i.e. January to March (Hew; Yong, 2004) when it is extremely cold. On the other hand, during January to March, cymbidium orchid in Southern part is in recession and it is not possible to produce a low-cost product. So, Iranian products do not have a serious competitor for orchid production.

Orchids is a monocot plant that called Saleep in Persian and Arabic literature. Saleep is mentioned frequently as a medicinal plant (Dressler, 1990). Cymbidium or boat orchids is a genus of 52 species of orchids. Cymbidium plants are in sympodial form and grow to the height of about $60 \mathrm{~cm}$. Floral part grows from the base of young pseudobulbs (Crib; Puy, 2007). Agha Oghlu et al. (1995) reported that Turkey's orchids grow better in the medium with pH 6.5. Ors et al. (2010) recommended that orchid plants require rich organic matter in the medium and they concluded the type of mycorrhizae in the soil and climate factors of region are more effective in orchid species distribution than soil characteristics. Yong and Hew (1995) showed that carbon produced in the leaves was transferred first to pseudobulbs and that the absorption of minerals from the medium and both of them help flowering induction.

Wang (1996) found that peat moss is very suitable for orchids since it preserves moisture in the medium and maintains more nutrients. According to Oriozco et al. (1997), the physical condition of the soil is important for the cultivated orchids. They declared that the physical form of the substrate must be able to keep the adequate air and water for orchid life. In a study on the effect of hydroponic medium on the quality of growth and flowering of orchids Oncidium, Hsu and Lin (2005) used rockwool, sphagnum and a mixture of rocks, pine bark and coal equally. Sahin and Anapali (2006) mentioned the soil particles grading as an important factor for determining the absorption, aeration, irrigation, porosity and water loss in the development of some media. Marden fitch (2006) suggested sphagnum moss alone for the planting old pseudobulbs of Cymbidium orchids. Kang and Freeman (2007) used the peat moss for the effect of microorganisms on the enzymatic activity the Orchid Dactylorhiza. In a survey on the effect of size of pseudobulbs and temperature on flowering Odontioda orchids, Blanchard and Runkle (2008) selected a medium with $75 \%$ compost $+15 \%$ Perlite $+10 \%$ peat sphagnum. In a study on the effect of temperature and age of pseudobulbs on flowering orchids Miltonopsis, Batchman (2009) recommended a composition of medium Cymbidium orchid containing at least $20 \%$ perlite with coconut and shell pieces. Ors et al. (2010) sampled 36 soil types in eastern part of Anatolia in their study on the physical and chemical properties of soil in East Turkey as habitation of Epiphyte Orchids.

In this research, it was tried to optimize the cheap method for mass production of cymbidium orchids to increase production worthiness. To achieve this goal, the application of old pseudobulbs (which, otherwise, are disposed) can be considered as a cheap source for the production of young plants. Pseudobulbs are storage organs of epiphyte orchids which are formed between the branches and roots; they can flower in 3-5 years after germination. But the aim of this study was to determine the appropriate medium for planting pseudobulbs at the least possible time.

\section{Material and Methods}

This study was carried out in the Nowshahrgol greenhouse (Nowshahr, Iran) in a randomized complete block design (RCDB) with 5 treatments in 3 replications. It used 15 pots in which 5 bulbs were planted. Back-bulbs were collected from greenhouses in northern Iran. The back-bulbs were grown in a plastic covering greenhouse $\left(500 \mathrm{~m}^{2}\right)$ under natural light which provided a $15 \mathrm{~h}$ photoperiod, temperatures of $18-25^{\circ} \mathrm{C}$ and relative humidity $75 \%$. The experimental greenhouse dimensions were: $10 \mathrm{~m}$ wide, $50 \mathrm{~m}$ long, and $6 \mathrm{~m}$ roof height.

Treatments were pure perlite (T1), perlite + sand (T2), pure sand (T3), cocopeat + sand (T4) and cocopeat + perlite (T5). To prepare the pot mediums, perlite was carefully washed with water until fluorine was reduced and fine particles and aggregation did not affect the medium. Perlite + sand in the second medium was in equal proportion (1:1). In the third medium, sand was carefully washed to remove salts from the medium. Treatments in the fourth and fifth media were also in equal proportion (1:1). All media were disinfected by Benomyl $\left(2 \mathrm{~mL} \mathrm{~L}^{-1}\right)$. Before planting, back-bulbs were also immersed in a solution of $1.5 \mathrm{~mL} \mathrm{~L}^{-1}$ Benomyl for $10 \mathrm{~min}$ and then were raised vertically to a depth of one- 
third the height of the old pseudobulbs in different media. After 180 days, all back-bulbs were taken out of the media and young plants were raised from dormant buds were investigated. The estimated traits including minimum and maximum root and leaf, root number and leaf number were measured. At the end of the experiment, all the root and leaf traits of plants were measured in each plot and their means were analyzed as the plot data. Analysis of variance of data was carried out using MASTATC and SPSS statistical software. Also, means were compared by the Tukey's test.

\section{Results and Discussion}

The results of analysis of variance for the number of root, root length and leaf length are explained below in Table 1 and 2. Table 1 shows that the effect of trial treatments (medium) was significant on the rooting of bulbs $(\mathrm{p}<0.01)$.

Table 1. The results of analysis of variance for some trial traits

\begin{tabular}{lclcc}
\hline $\begin{array}{l}\text { Sources of } \\
\text { variation }\end{array}$ & df & & \multicolumn{3}{c}{ Means of squares } \\
\cline { 3 - 5 } & & & & \\
Reot length & Leaf length & Root \\
Factor A & 4 & $7.72^{\text {** }}$ & $3.66^{\mathrm{ns}}$ & $0.04^{\mathrm{ns}}$ \\
Error & 8 & 1.54 & $27.18^{* *}$ & $1.28^{* *}$ \\
\hline CV $(\%)$ & 2 & 3.09 & 0.15 \\
\hline **: Significance at $1 \%$, ns: no significance. & & &
\end{tabular}

Table 2. Means comparisons for the effect of treatments on traits

\begin{tabular}{lccc}
\hline Medium & $\begin{array}{c}\text { Number of } \\
\text { root }\end{array}$ & $\begin{array}{c}\text { Leaf length } \\
(\mathrm{cm})\end{array}$ & $\begin{array}{c}\text { Root } \\
\text { length }\end{array}$ \\
\hline Pure perlite $\left(\mathrm{T}_{1}\right)$ & $4.53 \mathrm{a}^{*}$ & $13.43 \mathrm{a}$ & $7.53 \mathrm{a}$ \\
Perlite + sand $\left(\mathrm{T}_{2}\right)$ & $4.13 \mathrm{a}$ & $6.03 \mathrm{~b}$ & $3.79 \mathrm{~b}$ \\
Pure sand $\left(\mathrm{T}_{3}\right)$ & $2.91 \mathrm{~b}$ & $8 \mathrm{~b}$ & $4.45 \mathrm{~b}$ \\
Cocopeat + sand $\left(\mathrm{T}_{4}\right)$ & $4.17 \mathrm{a}$ & $7.68 \mathrm{~b}$ & $6.92 \mathrm{ab}$ \\
Cocopeat + perlite & $4.46 \mathrm{a}$ & $6.22 \mathrm{~b}$ & $5.12 \mathrm{~b}$
\end{tabular}

\section{$\left(\mathrm{T}_{5}\right)$}

*In each column, means followed with the same letter(s) are not significantly different at $1 \%$ level of probability according to the Turkey's test.

Means comparison (Table 2) shows that the best treatment on rooting was pure perlite (T1). Pure sand had minimum rooting $(2.91 \mathrm{~cm})$. Other media (T2: perlite + sand, T4: cocopeat + sand, T5: cocopeat + perlite) did not have significant difference with $\mathrm{T} 1$.

Because of its good performance, perlite was found to be the best medium. Its $\mathrm{pH}$ is neutral and its texture facilitates rooting. Thomas and thomas (2005) planted Odontioda orchids in the hydroponic with $100 \%$ perlite at the Perlite Institute of America and reported suitable rooting, growth and flowering. The results are likely to be affected by the porosity of the perlite particles. Also since perlite is heated at $650^{\circ} \mathrm{C}$ and lacks biodegradable materials, it can be an appropriate medium that minimizes the possibility of contamination during rooting. In other research on strawberry, the authors reported that the highest significant values of vegetative growth, yield and its component were recorded for plants grown in perlite: peat-moss mixture (EL-SAYED et al., 2016).

Based on means comparison for the effect of trial treatments on the leaf length (Table 2), maximum leaf length was obtained from pure perlite (T1) and minimum one was obtained from perlite + sand (T2). Other treatments (T3, T4, T5) were significantly different with T1. Batchman (2009) stated that young and mature plants of Cymbidium orchids have good yield in the certain degree of aggregation of the fine perlite. He suggested the application of organic matter for the best growth.

Such advantages as high porosity, lacking exchangeable cations and nutritional control changes leaf growth in hydroponic culture. Perlite + sand was found to be less appropriate due to leaching of nutrients, while other media were relatively appropriate due to moisture and nutrient. In this respect, Ergene (1993) stated that different forms of the media are effective on the optimal absorption of micronutrients and are regarded as the most important factors in the emergence of deficiency symptoms in plants. Perlite + peat gives the best result for leaf length of Leucojum aestivum (KAHRAMAN, AKÇAL, 2016). In our experiment, pure perlite was more effective than cocopeat + perlite mixture.

According to means comparison for the effect of trial treatment on the root length (Table 2), the highest root length was obtained from pure perlite treatment (T1) and lowest root length was obtained from plant treated with perlite + sand (T2). The highest average value for root length of Leucojum aestivum were measured in cocopeat (KAHRAMAN, AKÇAL, 2016).

According to table 2, pure perlite creates favorable conditions for the growth of roots because of its neutral $\mathrm{pH}$ and appropriate porosity. Batchman (2009) reported that Cymbidium likes slightly acidic soil with good porosity and that the soil should contain at least $20 \%$ perlite for gardeners. In this case, cocopeat + sand medium was effective for orchid's roots during the vegetative stages because of moisture retention, appropriate $\mathrm{pH}$ and structure of cocopeat and organic matter. Table 3 is based on the results of analysis of variance.

Some traits including the least root length, maximum root length, leaf number, leaf length and average leaf length were not significantly affected by the studied media. 
Table 3. The results of analysis of variance for the effect of different media on some measured traits

\begin{tabular}{|c|c|c|c|c|c|c|}
\hline \multirow[b]{2}{*}{$\begin{array}{l}\text { Sources of } \\
\text { variation }\end{array}$} & \multirow[b]{2}{*}{ df } & \multicolumn{5}{|c|}{ Means of squares } \\
\hline & & $\begin{array}{l}\text { Minimum root } \\
\text { length }\end{array}$ & $\begin{array}{l}\text { Maximum root } \\
\text { length }\end{array}$ & $\begin{array}{c}\text { Number of } \\
\text { leaves }\end{array}$ & $\begin{array}{l}\text { Maximum leaf } \\
\text { length }\end{array}$ & $\begin{array}{c}\text { Mean leaf } \\
\text { length }\end{array}$ \\
\hline Replication & 2 & $4.56^{\mathrm{ns}}$ & $22.463^{\mathrm{ns}}$ & $0.185^{\mathrm{ns}}$ & $0.563^{\mathrm{ns}}$ & $0.232^{\mathrm{ns}}$ \\
\hline Factor A & 4 & $9.266^{\mathrm{ns}}$ & $27.924^{\mathrm{ns}}$ & $0.409^{\mathrm{ns}}$ & $6.872^{\mathrm{ns}}$ & $11.635^{\mathrm{ns}}$ \\
\hline Error & 8 & $10.635^{\mathrm{ns}}$ & $18.394^{\mathrm{ns}}$ & $0.447^{\mathrm{ns}}$ & $13.837^{\mathrm{ns}}$ & $6.139^{\mathrm{ns}}$ \\
\hline $\mathrm{CV}(\%)$ & - & 109.44 & 42.45 & 52.12 & 14.95 & 14.80 \\
\hline
\end{tabular}

ns: no significance.

While, according to Kahraman and Akcal (2016), substrates had a significant effect on bulb diameter, bulb height, bulb weight, stem and leaf weight, dry stem and leaf weight, leaf number, leaf length, leaf thickness, leaf width, root length, root weight and dry root weight of Leucojum aestivum. However, there was no significant difference between substrate treatments for the stem diameter. These results revealed that responses of Cymbidium orchid were different from Leucojum aestivum to substrates.

The survey results indicated that the best treatment is pure perlite. Choosing a pure medium induced the production of roots and improved vegetative organs such as leaves and roots, and so it is considered the best option. Perlite resulted in significant measures during the emergence and growth of latent buds and the growth of the leaves because of its capillary action, neutral $\mathrm{pH}$ and appropriate humidity retention. Since Cymbidium medium could easily re-absorb moisture during the experiment, the young plants were never affected by drought or flood stress, and at the end of the experiment, they look extremely fresh compared with other treatments.

\section{Conclusions}

Finally, Cymbidium orchid was already influenced by media. Pure perlite is the best option to produce young plants from back-bulbs. It is recommended that sowing operations be done after flowering in spring. In autumn and winter the back-bulbs remain in dormant state until vegetative growth in spring. NPK fertilizer is recommended in 20:20:20 proportions.

\section{Bibliographic References}

AGHA OGHLU, Y. S.; CELIK, H.; CELIK, M.; FIDAN, Y.; GULSEN, Y.; GUNAY, A.; HALLORAN, N.; KOKSAL, A. L; YANMAZ, R. General horticulture (in Turkish). Ankara University, Agriculture faculty. Ankara, v. 8, n. 3, p. 10441050. 1995

BATCHMAN, L. Cymbidium potting mixes. CSA Journal. Pasadena, v. 9, n. 5. p. 35-37. 2009.
BLANCHARD, M. G.; RUNKLE, E. S. Temperature and pseudobulb size influence flowering of odontioda orchids. Hortscience. Alexandria, v. 43, n. 5, p. 1404-1409. 2008.

CRIB, P.; PUY, D. The genus cymbidium. Beccles: Kew Publishing, 2007. 369 p.

DRESSLER, R. L. The Orchids: natural history and classification. London: Harvard University Press, 1990. 332 p.

EL-SAYED, S. F.; HASSAN, H. A.; ABUL-SOUD, M.; GAD, D. A. M. Effect of different substrates and nutrient solutions on vegetative growth, mineral content, production and quality of strawberry. Zagazig Journal of Horticultural Science. Zagazig, v. 43, n 6A, p. 1919-1938. 2016.

ERGENE, A. Principle of soil science. Erzurum: Ataturk University, Agriculture Faculty, 1993. 560 p.

HEW, C. S.; YONG, J. W. H. The physiology of tropical orchids in relation to the industry. Singapore: World Scientific, 2004. 370 p.

HSU, J. H.; LIN, R. S. Effect of cultural medium and hydroponic culture on growth and flowering quality of Oncidium Gower Ramsey. Acta Horticulturae. Seoul, v. 761, p. $489-493.2005$.

KAHRAMAN, O.; AKÇAL, A. The enlargement of leucojum Aestivum $l$. in different substrates under greenhouse condition. Scientific Papers Series B, Horticulture, v. LX, p. 191-198. 2016.

KANG, H.; FREEMAN, C. Interactions of marsh Orchids (Dactylorhiza spp.) and soil microorganisms in relation to extracellular enzyme activities in a peat soil. Pedosphere. Beijing, v. 17, n 6, p. 681-687. 2007.

KIAEE, J. Research in Iran's flower market. Tasnimnews. Tehran, p. 9-10. 2011.

MARDEN FITCH, C. Orchid portraits, vegetative propagation. American Orchid Society Bulletin, v. 74, n 5, p. 2006. 342-347. Ready in: http://www.aos.org/AOS/media/Content-

Images/PDFs/VegetativePropagation.pdf. Accessed in May $25,2017$.

ORIOZCO, R.; GSCHWANDER, S.; MARFA, O. Substrate classification from particle size analysis. Acta Horticulturae. Freising, Germany. v. 450, p. 397-403. 1997.

ORS, S.; SAHIN, U.; ERCILI, S.; ESITKEN, A. Physical and chemical soil properties of orchid growing areas in Eastern Turkey. Journal of Animal and Plant Sciences. Lahore, Pakistan. v. 21, n 1, p.60-65. 2010. 
SAHIN, V.; ANAPALI, O. Addition of pumice affects physical properties of soil used for container grown plants. Agriculturae Conspectus Scientificus. Zagreb, v. 71, n. 2, p. 59-64. 2006.

THOMAS, W.; THOMAS, B. Growing orchids in perlite. Charles Island Gardens, West Vancouver, Canada. The Schundler Company, p 1-2. 2005. Ready in: www.schundler.com/orchids.htm. Accessed in: May 25, 2017.
WANG, Y.T. Effect of six fertilizers on vegetative growth and flowering of Phalaenopsis orchids. Scientia horticulture. Amsterdam, v. 65, p. 191-197. 1996.

YONG, J.W.H.; HEW, C.S. Partitioning of 14C assimilates between sources and sinks in the sympodial thin-leaved orchid, Oncidium goldiana. Plant Science. Clare, v. 156, p. 188-196. 1995. 